\title{
INDUSTRIAL TRAINING IN THE STATE OF SELANGOR, AS A COMPLEMENT TO THE CURRICULUM OF NAQLI AND AQLI KNOWLEDGE INTEGRATION: A SURVEY OF ORGANIZATIONS FAVOURED BY THE STUDENTS OF THE FACULTY OF QURANIC AND SUNNAH STUDIES, UNIVERSITI SAINS ISLAM MALAYSIA
}

\author{
Mohamed Akhiruddin Ibrahim ${ }^{1}$ *, Adnan Mohamed Yusoff ${ }^{2}$, Mohammad Hikmat \\ Shaker $^{3}$, Abdul Qadir Usman Alhamidy ${ }^{4}$, Safiah Shariff Sheriff ${ }^{5}$, Raimizar Rahim ${ }^{6}$, \\ Abdul Rahman Zakaria ${ }^{7}$ \\ ${ }^{1}$ Senior Lecturer, Dr, Universiti Sains Islam Malaysia, MALAYSIA, akhiruddin@usim.edu.my \\ ${ }^{2}$ Dean, Assoc Prof, Dr, Universiti Sains Islam Malaysia, MALAYSIA \\ ${ }^{3}$ Senior Lecturer, Dr, London Open Academy, UNITED KINGDOM \\ ${ }^{4}$ Senior Lecturer, Dr, Universiti Sains Islam Malaysia, MALAYSIA \\ ${ }^{5}$ Language Teacher, Universiti Sains Islam Malaysia, MALAYSIA \\ ${ }^{6}$ Language Teacher, Universiti Sains Islam Malaysia, MALAYSIA \\ 7 Student, Universiti Sains Islam Malaysia, MALAYSIA \\ ${ }^{*}$ Corresponding author
}

\begin{abstract}
Industrial training has become an important activity for every higher learning institution these days. It is a form of experiential learning for a student after going through a period of acquiring theoretical knowledge in the lecture room. It does not have a standard scale for all universities around the world in terms of the time and duration of training. Some universities set it for a period of one semester and some set it to be longer than a semester of study. In terms of time to undergo the training, some institutions specified that students have to undergo training during the final semester, i.e the study session for the whole bachelor's degree level ends as soon as the student has completed his or her training. While some institutions require students to return and continue their study at the university, after completing their industrial training session. As for students of the Faculty of Quranic and Sunnah Studies, Universiti Sains Islam Malaysia, they are required to undergo this training in the eighth semester, i.e. at the last semester of the final year of their bachelor's degree programme. Upon completion of the industrial training session, they are considered to have completed the curriculum at that level. It is during this training that students practice what they have learnt through out all the lectures at the faculty, especially the integrated knowledge of Naqli and Aqli. This study looked at some organizations which are favoured by students of the faculty as their choice for industrial training in the state of Selangor, Malaysia. The organizations that are frequently preferred by students namely are Awan Metro Sdn Bhd, Darul Syakir Enterprise, Islamic Religious Office of Kuala Langat District, National University of Malaysia, Transform Training \& Consultancy, Faqeh Foundation, Akademi Fakih Intellect, Tabung Haji Office, PTS Media Group Sdn Bhd and Selangor Institute of Dakwah and Training. These organizations have various different backgrounds such as federal government departments, state government departments, statutory bodies, non-governmental organizations and private companies. In
\end{abstract}


conclusion, the students of the Faculty of Quranic and Sunnah Studies of the Universiti Sains Islam Malaysia are interested in organizations of various backgrounds regardless of whether they are private companies or government departments in gaining experience and exposure for their industrial training.

Keywords: Industrial training, curriculum, Naqfi and Aqli, Selangor, Universiti Sains Islam Malaysia.

\section{INTRODUCTION}

The industrial training is one of the practical learning processes before the tertiary academic session ends. Since the university applies the Naqli and Aqli approaches in its curriculum, this training is necessary to ensure that the students apply all the knowledge learnt throughout the learning process. By following the industrial training programme, the students will get an opportunity to gain experience of working life firsthand. This article surveys the organisational preferences of students in Selangor, which is next to Negeri Sembilan where the Universiti Sains Islam Malaysia is situated.

\section{ORGANISATIONS OPTIONS}

Before the students go for their industrial training, they are given the opportunity to choose any organisation which they prefer as long as it is in accordance with their field of study. The selection of the organisation is influenced by the distance to the place of residence and its safety. Based on the reviews conducted, The organizations that the Faculty of Quranic and Sunnah Studies students most frequently preferred are:

\subsection{Kuala Langat District Islamic Religious Office}

Kuala Langat District Islamic Religious Office is located in Banting, Selangor. The work scope of this office are education and services as it consists of eight main units which are; Religious Education Unit, Administrative Unit, Family Law Unit, Dakwah Unit, Mosque Management Unit, Research and Development Unit, Enforcement Unit and Prosecution Unit.

The Administrative Unit usually handles administrative matters. This unit will perform clerical duties to maintain an organised healthcare office and allows all staff to focus on their work. This unit also maintains a line of communication between leader and staff. It also manages the monthly leave and the welfare of employees. Meanwhile, Tthe unit of Family Law deals with the issues related to marriage, divorce, ruju' matter, counseling and pre-marriage courses. In Selangor, when someone wants to get married, they should sign up the online form to register the marriage permission form.

In addition, Tthe Religious Education Unit is responsible for the planning, implementing and learning of The Quran, Jawi, Fardh Ain, Selangor SRA, SRAI, and KAFAl among the children's and youth in primary school. The Dakwah Unit is assigned to organise the programmes about Aqeedah, Sharia, Akhlak and Islam in the community. However, Ithe Mosque Management Unit is the only unit responsible for ensuring that all matters related to the mosque go smoothly. It also manages the allowances for teachers, imams, bilals and takmir of the mosque.

Moreover, Fthe Enforcement Unit acts like a police, but it does not chase criminals. They react when they received a complaint related to religious criminals and go to the location to catch the offender immediately. The offenders will be brought to the police station to give their testimony. The next day, the offender is required to go back to the office to be counselled and fined.

The Kuala Langat District Islamic Religious Office is one of the public services that focuses on Islam. The vision is "The Best, World-Class with the Blessing of Allah". Besides, the mission is to manage the Islamic affairs with wisdom, trust and to be effective. The motto of Kuala Langat District Islamic Religious Office is "Wisdom, Trust, and Efficiency". The objective that they hold is to generate a Holistic Islam amongst community through Islamic institutional infrastructure and the best delivery service that is efficient and impressive. Besides, they also provide strong religious education to Muslims in Selangor and implement a plan and monitor the development of Islamic family programmes.

During the industrial training, students have gained so many benefits from this industry. When they are working at the Family Law Unit, they learnt how to meet customers and provided services to them. At the beginning, they have been exposed on how to serve the customers as to entertain people who want to deal with certain religious matters. After one week, they will be moved to the Enforcement Unit. They never miss the opportunity to participate inevery enforcement operation to prevent vices 'maksiat'. They also learn about Criminals Enforcement and Religious Criminals act. Also, the students are placed in Syarie Court and 
witness the criminal cases being tried (Izzati, 2015).

\subsection{Institut Latihan dan Dakwah Selangor}

Institut Latihan dan Dakwah Selangor (ILDAS) or Selangor Missionary and Training Institute is a training institution that was built under Jabatan Agama Islam Selangor (JAIS). The operation of this institution started in 1995 at Sabak Bernam town and was known as Pusat Dakwah Selangor (PDS). In 20 May 2009, the PDS moved its operation to a new building in Sungai Lang, Sabak Bernam with the name of (ILDAS). The opening ceremony of the ILDAS was completed by Duli Yang Maha Mulia Sultan Salahuddin Abdul Aziz Shah Al Haj, Sultan Selangor Darul Ehsan, and The Deputy of Selangor Sultan in 25th November 2000.

Since its establishment until today, the ILDAS remained consistent with its courses and its training aimed at participants from JAIS staff as well as public. The courses were implemented through the establishment of five training centres that functioned as secretariats for the courses. The five training centres consisted of General Management Training Centre (PLPA), Dakwah Management Training Centre (PLPD), Information Technology Management Training Centre (PLPTM), Islamic Education Management Training Centre (PLPPI) and Mosque Management Training Centre (PLPM). Most of the courses were implemented by ILDAS based on the module prepared to train JAIS staff with the purpose of gaining success, progressiveness, dynamic, and blessings from Allah. ILDAS also ensured the accomplishment of vision, mission, and objectives targeted.

At the Selangor Training and Dakwah Institute (ILDAS), the students gained more knowledge which implicitly helped them prepare mentally and physically before entering the real work field. Most of the time, the trainee spent their time at the department to assist the staff. Although ILDAS comprises five training centres, however the task distributions as similar as among all centres. All centres require their staff to handle courses. The difference between these five training centres consists in the participants who attended the course. Each department has its own roles and responsibilities that need to be implemented successfully. In addition, the student also involved in an outstation program named Kembara Dakwah Ex-PSDK for a week at Grik, Perak. This program was under PLPD (Saadah, 2015).

During the internship period at ILDAS, the trainees were placed at five training Centres. The distribution to training centres was done in the first week. Each of the trainee carried out the duties for three weeks, thereafter the trainees were shifted to the other training Centres.

\subsection{Transform Training \& Consultancy}

Transform Training \& Consultancy is located at No 11B (2nd Floor), Jalan Medan PB 2D, Seksyen 9, 43650 Bandar Baru Bangi, Selangor. Transform Training \& Consultancy is a training institution that offers training services and consulting in quality and integrity for the country. The goal and vision are to develop human resources to be more productive and competitive. Transform Training \& Consultancy realise that all the workers in Malaysia must undergo in-service training from time to time to enhance their knowledge and skills in the profession or field of work to be more skilled, competent, motivated, responsible and able to improve the productivity and organisational excellence. These objectives can be achieved through training programmes and talks arranged systematically.

Transform Training \& Consultancy possesses a speaker and a trained motivator of calibre and experience in forming, carrying out and assessing the training programmes conducted for the royal agencies, private institutions and banking institutions, corporate institutions and non-Governmental Organization (NGO), teaching institutions and high schools. In order to ensure the company's business runs smoothly and systematically, Transform Training \& Consultancy has a management team with extensive experience in consulting and training consisting of director, main consultants, administrative manager, training manager and programming manager.

The vision of this company is to develop human resources to become more productive and competitive. The mission of the training programmes is designed according to the needs of the participants and the organisation. Besides, the training conducted gives positive impressions in terms of its effectiveness and practice. Furthermore, the transformation training provides the best training to stimulate change in the individual as a whole (mental, physical, spiritual, emotional and social). As it is known, $75 \%-80 \%$ of human thinking is negative. The training is emphasized towards the purification of the mind and heart to turn into 'THE NEW' excellence, quality, productive and competitive. The objective of this company is to give a positive impact on the participants to produce a great staff, and students and to produce student and workers who have an appreciation of prayer so that they can implement the quality and discipline of their prayer in their daily life. So, only the 'Good' and 'Excellent' will be able to perform each role and responsibility in the 
best way.

The students who joined the industrial training at the Transform Training and Consultancy have been given a task to manage the list of the participants in some programmes like the Pro-kids Program, Family Sunnah and programme for corporate and school programme. In addition, they need to make sure that the programme goes on smoothly before and during the program. The third task is to take the information from the customers for booking of the programme. They also assisted the manager for business promotions. They also have to make proposals and quotations for the programme. And lastly, they can act as a facilitator for the camp and programmes (Aisyah, 2014).

Some activities that they joined are the pro-kids all (A) at the Photon Valley Resort, Hulu Langat, Selangor, Family Sunnah Seminar at UPM Serdang, pro- kids Smart Study at Photon Valley, Hulu Langat, Selangor and pro- kids Smart Study at Savannah Hill Resort, Ulu Tiram, Johor Bahru.

\subsection{Awan Metro (M) Sdn Bhd}

Awan Metro (M) Sdn Bhd is located at G-25 \& 1-25, Jalan Anggerik Perdana 2, Taman Anggerik Perdana, 43500 Semenyih, Selangor Darul Ehsan, Malaysia. In year 1994, Awan Metro (M) Sdn Bhd involves with the preparation of curriculum, Fardhu Ain (KAFA) under supervision of Jabatan Kemajuan Islam Malaysia (JAKIM). In this program, they decide to offer main resources for students, which are books as we call it "Buku Sumber" (Source Books) KAFA. JAKIM has decided to give a chance to all editors in Malaysia to publish and distribute the "Buku Sumber" (Source Books) by KAFA.

Awan Metro (M) Sdn Bhd has been constructed at 9 April 1994 to succeed JAKIM projects. Thus, this company getting trust from JAKIM to publish and distributed some of "Buku Sumber" (Source Books) by KAFA all the state in Malaysia. The company achieved success and now has complete facilities to publish all books as a one stop centre. In 7 Mac 1997, mid modal Industries Sdn Bhd has been developing to get their own printing and banding machines.

After that, In 5 May 1997, Karisma Maya Sdn Bhd has been developed for transportation and delivery purpose. The branch has been multiplied and this is getting the purpose which is taking more projects and assisting other project in trouble. The services include organizing Word, Designing, Advertising (printed), Publish Text Book and other books, Billboard, Audio, Visual, Photography, Drafting, Stationery, Electronics devices, Printing and Translate devices (Amirah, 2014).

The company motto is "your desire is our inspiration". The company vision and mission is to be big organization and sturdy. The vision is also to be a top publisher in public or private education field. They also want to be a publisher in local and international area. The mission of this company is to offer the best service to customers in terms of quality, punctuality, and quick and skillful after-sales services. The longest relationship between customer and company can raise the company to advance level, which one can be proud of in the present advanced technology era.

In addition, Awan Metro Sdn Bhd will continue to offer more products and services. They have several services like pre-press (process before printing), press (printing process), post-press (process after printing) and delivery (delivery process). The company delivers such products and services as advertisement, publishing and textbooks suppliers, common books, public and private universities books, homework books, magazines and year report, gift books, posters and folders, calendar, letterheads and bunting, banner and backdrop.

This part will explain the details of tasks and activities that have been made during the Industrial Training at Awan Metro Sdn Bhd. Since the students' skill incline more toward multimedia field, their supervisor assign them some coursework related to multimedia studies, such as develop courseware. In addition, the students were also given the assignment to retype the books from the publishing company to print. Then, they were also given the task of re-editing undone textbooks provided by the author. They need to share some assigned work with each other to speed up the completion of the assignment.

This company is known as a company gains profits from textbooks, common books, bunting order, banners and others that connect with writing. Therefore, during internship, students have their own contribution to the company, which helped the company to finish 8 textbooks for the benefit of the company. The textbooks that they have contributed are a Japan Language Form 5, Al-Quran, the meaning of Al-Quran in Jawi, Maharat Quran Form 1, Syariah Form 1, Usuluddin Form 1, Hifz Quran and Arabic Language Form 1. Other than that, they also contributed to producing Yaaseen courseware, which will be published through the company. With this courseware, the company can gain more profit. 


\subsection{Darul Syakir Enterprise}

Darul Syakir Enterprise is located at No 6, Jln 4/12A, Seksyen 4 Tambahan, 43650 Bandar Baru Bangi, Selangor. Darul Syakir Enterprise is one of the private companies that was established in 1998. Darul Syakir is a company that publishes and distributes books. The company publishes books in this country and abroad. In this company, they give many services for their customer. This company is very popular in among universities lecturers such as, National University of Malaysia (UKM), International Islamic University College of Selangor (KUIS), Sultan Zainal Abidin University (UNISZA), International Islamic University of Malaysia (IIUM), Malacca Islamic University College (KUIM) and Universiti Sains Islam Malaysia (USIM) since they publish their books in this company. Until now, this company has provided the same services:

The company vision is to become a competitive and advanced company in Bangi. The mission is to provide the best services for customers and to offer the best and high quality supply and distribution of educational materials. Besides that, they want to assist customers from universities and government bodies. The company's objective is to provide publications, distribution and publishing services. They also want make a commitment to supply and distribution of educational materials in the form of printed or electronic media necessary for libraries, public and private universities, and government bodies. Lastly, they want to provide the best quality products and services as well as innovative according to market and customer demands.

This company organization chart is headed by its marketing manager, Mr. Mohd Suhairi Bin Sahimi. He holds a Bachelor's degree in Business Management from University Utara Malaysia. He has experience of 5 years in the field of marketing and sales. The assistant marketing manager is Mr. Mohd Syaiful Nizam Bin Rabu. He holds Bachelor's degree of Muamalat Administration from Islamic Science University of Malaysia. $\mathrm{He}$ has one year experience in marketing and sales. Lastly, the Administrative and Finance Manager, Mrs. Adawiyah Bt Mohd Tajudin, holds a Diploma and has experience in administration for 3 years. The company has made several products and services like importing books, importing journals and magazines, distributing printed materials, accepting orders, participating in book affairs, subscribing to online magazines, publishing student university books, publishing Islamic books and many more.

Since student's skill are more inclined toward multimedia and computing field, their supervisor assign them some coursework related to computing studies, such as editing the book that will be published. Other than editing books, they also have to design the cover book to get the book ISBN, design their pamphlet for their promotion in book fairs. Other than that, they also have to attend book fairs in several places key in data of books that they save, and also make "a publication" or in the Malay language "sebuah terbitan" to put in the front page of the book. During the completion of the task given, practical student have been assigned to do work in team or individually. Therefore, they need to share some tasks given with each other to speed up the completion of the editing a book (Aqmar, 2016).

The other task is to attend book fairs in universities and colleges. The first place that student visited was the International Islamic University College of Selangor (KUIS). They spent one week there. The location-was in KUIS Mosque. The second location was the University College of Melaka (KUIM). In this task they went to Melaka to attend the book fair. They all stayed there for 4 days only. Next location was the National University of Malaysia (UKM). They went to UKM to attend the book fair.

\subsection{PTS Media Group Sdn Bhd}

PTS Media Group Sdn Bhd was founded in 1988 and it was established on 12 April 2000 as a general trade publisher for the Malay speaking readers. Since its founding day, the company has steadily expanded from its modest beginning of a small dedicated team into a full-fledged publishing organization. This company has now transformed and comprise key independent and established units and departments, while interlocking with each other to bring out the best in their functions for the benefits and growth of PTS. In general, this company holds to the policy of maintaining the copyright of the books it publishes to the authors of the book. Therefore the copyright of the books published by PTS remained owned by the author. PTS is just a medium for the author to publish their works. On the contrary, there are some authors who choose to sell their copyright for several reasons. For instance, the books' contents are not durable in the market, thus the author permits PTS to publish, distribute, and sell their books (Jameelah, 2016).

The students were placed in the Non Fiction Department. Basically, their job scope only covered translation task, editing and publicizing. For instance, they translated the Middle East tagging map in the book, Perang Atlas Salib. Apa Salah Syiah?, Antara Eksploitasi Dan Realiti, Jejak Ibnu Batutta Menelusuri Legasi Islam Abad Ke-14 And Bahagianya Apabila Hajimu Diterima Allah were among the books that they had publicized and reviewed. Apart from the editing task, they are also capable of doing tasks in Multimedia. Sometimes, they assisted the staff in the Fiction Department to obtain more knowledge. They learn to use an Apple PC in 
creating Tunas Super Video. They were involved in photo-shoot for "Ustaz, berapakah umur ahli syurga?" book's cover at Taman Layang-Layang.

\subsection{Tabung Haji Sabak Bernam}

Tabung Haji Sabak Bernam is a branch of Tabung Haji District in Selangor Darul Ehsan. The operation started on 1 August 1975. It is located at a local council building in Sungai Besar. Previously, it was located at Sabak Bernam town and then moved to Sungai Besar town on 21 April 1975.

Incorporated from Tabung Haji was the manifestation of the Government's concerns over the welfare of pilgrims in their pilgrimage to the Holy Land as well as their economic well-being. In 1969, in accordance with the Parliament Act 1969, Tabung Haji was set-up as a quasi-government body. In 1995, the New Tabung Haji Act 535 (1995) was passed and enacted by the Parliament, which enabled Tabung Haji to extend its business in a Shariah-compliant investment area. These investments allowed Tabung Haji to expand its businesses in order to maximize the return of investments for its depositors. The students managed the process of key in the data into the online database for the opening of new accounts. The depositors' accounts were re-checked before printed. The data were printed using the format given. In addition to doing the typing and printing task, they were involved in the promotions for the children in Tabika Kemas. Their job was not only limited to administrative task, but also covered the social works. In promoting for children in Tabika Kemas to register a new account, they distributed flyers and some rewards to them (Kausar, 2016).

Equally important, they had done several researches to find the causes of long waiting lists for candidates to perform Hajj. The research is still in progress. The pending distributions were checked and summarized as well. They were also responsible in alerting the depositors on their turn to perform Hajj, updating the account book and new account registration.

\subsection{Faculty of Islamic Studies, National University of Malaysia}

National University of Malaysia, abbreviation of UKM (Universiti Kebangsaan Malaysia) is a public university located in Bangi, Selangor which is about $35 \mathrm{~km}$ south of Kuala Lumpur. It delivers programmes in hospitality; Universiti Kebangsaan Malaysia Medical Centre (UKMMC) Pusat Perubatan Universiti Kebangsaan Malaysia (PPUKM) is located in Cheras and also has a branch campus in Kuala Lumpur. There are 17,500 undergraduate students enrolled, and 5,105 postgraduate students, of which 1368 are foreign students from 35 countries. This university is one of five research universities in the country. It was ranked by The Times Higher Education Supplement (THES) at number 185 in its annual ranking of the world's top 200 universities for 2006.

At the beginning, the Faculty of Islamic Studies at National University of Malaysia has only two departments, the Department of Syariah as well as the Department of Usuluddin and Arabic Language Unit. On May 15, 1974, the Department of Arabic Studies and Islamic Civilization was established. Until now, the Faculty of Islamic Studies had five departments and one Arabic unit. The departments are the Department of Syariah, and Department of Usuluddin of Philosophy, Department of Arabic Studies and Islamic Civilization, Dakwah and Leadership Studies Department and the Department of the Quranic and the Sunnah.

In addition, mission of the faculty is to safeguard the sovereignty of Islamic Studies and Islamic science internationalizing nationally and internationally. The objective of the faculty is to ensure that all customers receive friendly, good and efficient hospitality. Besides, they want to ensure the quality and the objectives of ISO management undergraduate and graduate studies are implemented. They also want to ensure that research is carried out by academic staff and students are of high quality and in accordance with the set of guidelines. Finally, consultations are undertaken with various related parties to ensure effectiveness and quality. The students who undergo industrial training in this faculty, need to help update data of theses into system SPD UKM, etc and to follow any instructions given by their supervisors (Atiqah, 2014).

\subsection{FAQEH Foundation}

The Foundation of Quranic Education for Special Needs Children also known as FAQEH Foundation. FAQEH Foundation located in University Malaya, no.17, Jalan 16/4 Seksyen 1646350 Petaling Jaya, Selangor. As such, Islam places great importance on early childhood education through the concept of 'fitrah'. That is the inculcation of faith and The Quranic moral values. Undoubtedly, parents are 'Qudwah Hasanah' or the role model in educating children effectively, as portrayed by Rasulullah SAW.

FAQEH Foundation focuses on several important aspects in ascertaining The Quranic education for special children is delivered successfully. Aspects that are given priority include human capital development, use of appropriate methods and curriculum in teaching and learning, as well as economic generation through 
relevant programs and contribution from corporate organizations and the community. This foundation is an NGO organization that is organized to offer methods of teaching The Quran Education for special students.

In addition, this organization wants to have any collaboration with the universities in Malaysia to find an individual who is willing to help the disable students. They can contribute by teaching and educating the students. Above all, these efforts are the medium for da'wah as well. This foundation has set the vision to nurture a positive way of living for the generations among the special children based on The Quran. This Organization aims to organize The Quran Learning Classes for the disabled students (Hearing Problems, Sight Dysfunctions, Autism and Syndrome Down). Plus, it is aiming to become a medium for professionals and academicians to contribute to the "dakwah" activities by helping these disabled students. The mission is set to guide the disabled communities on how to approach, learn and know The Quran.

The training was done as the partial requirement for graduation and the students has successfully completed the internship for academic session every year. The students' first task was creating the teaching aids for deaf students. The teaching aids for deaf students were associated with picture and video to enhance the comprehension among the students. Besides, pictures and videos help in improving students' imagination (Zawiyah, 2015).

Since the students' skills were inclined more towards multimedia, Their supervisor assign them some coursework related to multimedia studies, such as creating videos. Other than creating video, they also have to create and design the PECs and cards that will be used for teaching and learning session according to the demand and level for each student. Other than that, they have done outdoor activities with the community During completing the task given, practical students have been assigned to do work in a team or individually. We need to share some work given with each other to speed up the completion of the task (Maryam, 2016).

\subsection{FAKIH Intellect Academy (AFI)}

$(\mathrm{AFI})$ is one of the centers that facilitate people, including the disabled people in reading The Quran and Ibadah. The Centre of Quranic Research (CQR) collaborates with the AFI in its own research in order to find out more facilitating approaches that could effectively help the disabled student to learn The Quran. The concern of this project includes those with Autism, Syndrome Down, Cerebral Palsy, Hearing Disability and Attention Deficit Hyperactivity Disorder (ADHD). The AFI benefits from The Quran as a source of cure to treat the disabled people's emotionally and spiritually.

One of the approaches in API is known as Fakih Method "Kaedah Fakih" that is based on numbers and colors. This innovative method is an outcome of a long experience of its pioneer Dr. Nor 'Aziah Mohd Daud and her friends who faced difficulties and hardships in their effort of teaching The Quran to the students with Hearing and Speaking disabilities. Nowadays, the "skip" method which is being practiced by most of the schools in Malaysia and it seems, in many cases, ineffective in teaching the disabled students (deaf and mute). Thus, it is observed that many of these particular students are discouraged from learning The Quran.

Mastering Quran among students with special needs must be taken seriously by all. Failure in exposing the Quranic knowledge to the disables will eventually influence their belief and lifestyle in the future. Awareness of this matter on the part of the students who study Islamic Studies will lead them to better understanding of The Quran. Furthermore, the concern will expose The Quranic culture among disabled students. The vision is to be an organization that helps develop the generation devoted to The Quran amongst the special needs children. The objective of this company is to create awareness among parents, teachers and the society on the importance of The Quran education for special needs children (Noornajihan, 2014).

Another is to carry out The Quran classes for children with hearing impairment, visual impairment and learning disorders, namely Autism and Down syndrome. AFI's mission is to provide quality educational infrastructures and facilities to serve The Quran education for special children and to collect and distribute funds for the development of The Quran education amongst special need children (Nor 'Aziah, 2012).

There are several tasks that have been given by student's supervisor; they were assigned the task to create the video for the book to be launched, which was published by Centre of Quran Research at University Malaya. They also joined International Seminar on Autism Malaysia 2014 which was the largest event of its kind held in Malaysia. The two days' seminar was indeed a great success and was recorded in the Malaysia Book of Records for the largest participants in an international seminar on Autism. FAQEH had been invited to set up booths at PICC Putrajaya, and they managed and promoted Quranic education at the booth.

\section{CONCLUSION}

There are various types of organizations in the State chosen by the students of the Faculty of Quranic and 
Sunnah, University Sains Islam Malaysia to attend the Industrial Training. There are organizations under the auspices of the State government, an organization under the auspices of the federal government, private companies, non-governmental organizations (NGOs) and statutory bodies. Based on the survey conducted, the majority of students choose private companies as compared to other organisations. This is because Selangor is a developed state that has a capacity of population and labour, there are many companies and business activities that are actively running. In addition, government departments, statutory bodies and nongovernmental organisations also have become an attraction for the students to undergo their industrial training, as one of the conditions for completing their studies.

\section{ACKNOWLEDGEMENT}

This paper presentation is funded by Research Management Centre, Universiti Sains Islam Malaysia, Grant no. (PPP/USG-0115/FPQS/30/11415).

\section{REFERENCE LIST}

Noornajihan Jaafar et. al., (2014), Vol. 5, Creative Education, Quran Education for Special Children: Teacher as Murabbi, pp. 435-436.

Nor 'Aziah Mohd Daud et. al., (2012), FAKIH: A Method to Teach Deaf People 'Reading' Quran, The 2nd Annual International Qur'anic Conference 2012 Proceeding, pp. 52-54.

Awan Metro (M) Sdn. Bhd., http://awanmetro.blogspot.myhttp://www.majalah.com/?business:awan-metro-msdn-bhd:C5YMDP3VDB4.

Centre of Quranic Research,http://car.um.edu.my/?modul=Events and Activities\&pilihan=FAKIH Learning.

Faqeh Foundation, http://www.yayasanfaqeh.org.my/home-page/programs.

Institut Latihan Dakwah Selangor, http://www.jais.gov.my/direktori/ildas.

Kuala Langat District Islamic Religion Office, http://www.jais.gov.my/artikel/paid-kuala-langat?q=artikel/visidan-misi-kuala-langat.

Lembaga Tabung Haji, http://www.tabunghaji.gov.my/akta-tabung-haji.

National University of Malaysia, http://www.ukm.my/sutra/index.php/about-ukm.

National University of Malaysia, http://www.ukm.my/v6/ukm-experts.

PTS Media Group Sdn. Bhd. http://pts.com.my.

PTS Media Group, http://everything.explained.today/PTS Media Group.

PTS Media Group, http://pts.com.my/rights/about-pts.

Selangor Islamic Religious Department, http://www.jais.gov.my/node/76.

Selangor Islamic Religious Department, http://www.jais.gov.my/content/khidmat-pengurusan.

Selangor Islamic Religious Department, http://www.jais.gov.my/node/76.

Selangor Islamic Religious Department, http://www.jais.gov.my/content/dakwah.

Selangor Islamic Religious Department, http://www.jais.gov.my/artikel/pendidikan-islam-0.

Selangor Islamic Religious Department, http://www.jais.gov.my/content/pengurusan-masjid.

Selangor Islamic Religious Department, http://www.jais.gov.my/content/penguatkuasaan.

Transform Training and Consultancy, http://www.transformjiwa.com/index.php/about-us.

\section{LIST OF STUDENTS (Interview):}

Felzazul Aqmar Abd Hamid (2016), Student, Faculty of Quranic and Sunnah Studies.

Maryam Jameelah Othman (2016), Student, Faculty of Quranic and Sunnah Studies.

Nur Amirah Kamarudin (2014), Student, Faculty of Quranic and Sunnah Studies. 
Nur Fariza Izzati Jamani (2015), Student, Faculty of Quranic and Sunnah Studies.

Nurul Atikah Hamidon (2014), Student, Faculty of Quranic and Sunnah Studies.

Nurul Kausar Mohd Nudi (2016), Student, Faculty of Quranic and Sunnah Studies.

Saa dah Abdullah (2015), Student, Faculty of Quranic and Sunnah Studies.

Siti Maryam Suandi (2014), Student, Faculty of Quranic and Sunnah Studies.

Siti Nuraisyah Zainuddin (2014), Student, Faculty of Quranic and Sunnah Studies.

Zawiyah Abdullah (2015), Student, Faculty of Quranic and Sunnah Studies. 